\title{
Effects of inorganic nutrients and zooplankton on the growth of heterotrophic bacterioplankton- enclosure experiments in an oligotrophic clearwater lake
}

\author{
Katarina Vrede* \\ Department of Limnology, Evolutionary Biology Centre, Uppsala University, Norbyvägen 20, S-752 36 Uppsala, Sweden
}

\begin{abstract}
Bacterioplankton production and abundance were studied in the oligotrophic clearwater Lake Njupfatet (Sweden) during 2 consecutive years (1989 and 1990). The lake was slightly acidic in 1989 and was limed during the autumn-circulation period that year. In June of both years, experiments were carried out in $300 \mathrm{l}$ bags immersed in the lake. Amounts of inorganic nutrients $\left(\mathrm{PO}_{4}\right.$ and $\left.\mathrm{NO}_{3}\right)$ and metazoan zooplankton in the bags were manipulated. In both years, additions of inorganic nutrients stimulated phytoplankton growth, and bacterial abundance, production and cell-specific production. Since phytoplankton growth was also stimulated, it cannot be concluded whether bacterioplankton growth was limited by inorganic nutrients alone or in combination with organic carbon provided by phytoplankton. The increase in bacterial biomass was smaller than expected based on the production measurements, especially in fertilized bags, indicating that there was strong grazing pressure on bacteria. In 1989, bacterial cell-specific production was enhanced by adding metazoan zooplankton, probably because zooplankton released nutrients that bacteria could utilize. Furthermore, the results indicate that the species composition of phytoplankton can affect the growth of bacterioplankton.
\end{abstract}

KEY WORDS: Bacterioplankton - Inorganic nutrients · Phosphorus - Nitrogen · Zooplankton - Enclosure experiments - Liming

\section{INTRODUCTION}

The regulation of bacterioplankton growth and biomass has been studied intensively over the last few decades. Organic carbon has been regarded as the most important nutrient regulating bacterioplankton growth (Rheinheimer 1992). However, several recent studies have shown that inorganic nutrients can also limit bacterial production (Toolan et al. 1991, Morris \& Lewis 1992, Schweitzer \& Simon 1995).

Lakes and marine coastal areas can have high concentrations of allochthonously derived organic carbon. In particular, humic lakes have high concentrations of dissolved organic carbon (DOC), owing to transport from the catchment area. Autochthonous organic car-

\footnotetext{
•E-mail: katarina.vrede@limno.uu.se
}

bon is probably of minor importance for bacterioplankton in this type of lake since bacteria can utilize allochthonous organic carbon (Tranvik \& Höfle 1987, Sundh \& Bell 1992). The ability of bacterioplankton to utilize allochthonous organic compounds is also reflected by the positive correlation between bacterioplankton biomass and humic content (Hessen 1985, Tranvik 1988). In humic lakes, inorganic nutrients are more important than organic substrates in regulating bacterioplankton growth (Hessen et al. 1994). The importance of organic carbon of autochthonous origin as a substrate for bacterioplankton is probably greater in clearwater lakes, which have lower concentrations of DOC compared with humic lakes. This also implies that processes within the lake (e.g. phytoplankton exudation, zooplankton grazing) may be of major importance in providing organic substrates for bacterioplankton. 
Bacterioplankton can obtain organic carbon from a variety of autochthonous sources. For example, it has been suggested that the extracellular release of organic carbon from phytoplankton is an important source of organic carbon (Münster \& Chróst 1990 and references therein). On average, the organic carbon released from phytoplankton accounts for less than $50 \%$ of the bacterial carbon demand, although this value varies widely (Baines \& Pace 1991). Jumars et al. (1989) suggested that the transfer of DOC from phytoplankton to bacteria occurs more in the form of byproducts of animal ingestion and digestion rather than via excretion of DOC directly from intact phytoplankton cells. The importance of zooplankton as a source of organic carbon has also been shown by Vadstein et al. (1989) and Peduzzi \& Herndl (1992). In addition, zooplankton can regenerate inorganic nutrients and thereby stimulate bacterial growth (Vareschi 1994, Sterner et al. 1995, Vrede 1998).

Bacterioplankton are grazed by members of protozoan and metazoan zooplankton, as well as by mixotrophic flagellates (Sanders et al. 1989). Heterotrophic flagellates are regarded as the major bacterivores and have been reported to often control bacterial abundance (Sanders et al. 1989, Berninger et al. 1991). However, their relative importance as bacterivores can vary over the season (Simek \& Straskrabova 1992). In addition, the top-down regulation of bacterioplankton abundance by heterotrophic flagellates seems to be most important in eutrophic systems, while in oligotrophic environments nutrient supply mainly regulates bacterial abundance (Sanders et al. 1992). Since metazoan zooplankton graze protozoan bacterivores (Burns \& Schallenberg 1996, Stensdotter-Blomberg 1998), a positive effect of metazoan zooplankton on bacterioplankton abundance and growth could be due to a reduction in bacterivores (a trophic cascade). Tranvik \& Hansson (1997) found a strong correlation between reduced copepod abundance, increased numbers of bacterivore flagellates, and decreased bacterial num- bers. On the contrary, Brett et al. (1994) found no effect of copepods or cladocerans on bacterial abundance.

In the present study the effects of inorganic nutrients (phosphorus and nitrogen) and metazoan zooplankton on bacterioplankton production and biomass were investigated in the oligotrophic clearwater Lake Njupfatet (Sweden). Effects on the phytoplankton community are discussed in detail elsewhere (Blomqvist 1997). In Lake Njupfatet, positive effects of inorganic nutrients (phosphorus and nitrogen) on bacterial production and biomass as well as on phytoplankton biomass were found in late summer during 2 consecutive years (Vrede 1996). In one year there was a close co-limitation of bacterioplankton growth by inorganic nutrients and organic carbon. Metazoan zooplankton stimulated bacterioplankton production one year but not in the other year. Changes in the bacterial response to the nutrients were attributed to changes in phytoplankton species composition. The present study was conducted during early summer. In contrast to the late summer investigation (Vrede 1996), in which zooplankton were studied at only 2 levels (absent or present at a concentration typical for the lake), the effects of zooplankton were investigated over a concentration gradient (absent to approximately 4 times ambient concentrations) in the present study.

\section{METHODS}

Study site. Lake Njupfatet is a dimictic, oligotrophic clearwater lake located in central Sweden at $62^{\circ} 01^{\prime} \mathrm{N}$, $16^{\circ} 23^{\prime} \mathrm{E}$. The drainage area of $0.62 \mathrm{~km}^{2}$ is dominated by mature coniferous forest. The lake has a turnover time of $2.5 \mathrm{yr}$, a mean depth of $4.3 \mathrm{~m}$, a maximum depth of $16 \mathrm{~m}$ and a surface area of $0.12 \mathrm{~km}^{2}$. The lake was naturally slightly acidic (Andersson et al. 1997) until it was limed in November 1989 (Table 1). The liming resulted in lower concentrations of total phosphorus and higher concentrations of DOC. Bacterial abundance in

Table 1. Chemical properties of the water in Lake Njupfatet in 1989 (before liming) and 1990 (after liming). Annual means and ranges are from composite samples from the respective years, and May values are from the epilimnion when the experiments started. TP: total phosphorus; SRP: soluble reactive phosphorus; TN: total nitrogen; DOC: dissolved organic carbon

\begin{tabular}{|c|c|c|c|c|c|c|}
\hline \multirow{2}{*}{ Parameter } & \multicolumn{3}{|c|}{1989} & \multicolumn{3}{|c|}{1990} \\
\hline & Mean & Range & May 30 & Mean & Range & May 31 \\
\hline $\mathrm{TP}\left(\mu \mathrm{g} \mathrm{Pl}^{-1}\right)$ & 9 & $6-13$ & 11 & 7 & $4-9$ & 7 \\
\hline $\operatorname{SRP}\left(\mu g P \perp{ }^{1}\right)$ & 1 & $<1-3$ & $<1$ & 1 & $<1-2$ & 2 \\
\hline $\operatorname{TN}\left(\mu g N l^{-1}\right\}$ & 242 & $171-301$ & 213 & 260 & $206-349$ & 250 \\
\hline $\mathrm{NO}_{3}\left(\mu \mathrm{g} \mathrm{N} \mathrm{l}^{-1}\right)$ & 11 & $<10-34$ & 23 & 25 & $10-78$ & 15 \\
\hline $\mathrm{NH}_{4}\left(\mu \mathrm{g} \mathrm{N} \mathrm{l}^{-1}\right)$ & 18 & $<2-50$ & $<2$ & 19 & $6-46$ & 19 \\
\hline $\operatorname{DOC}\left(\mu \mathrm{CCl}^{-1}\right)$ & 2760 & $2390-3340$ & 2690 & 3110 & $2540-4170$ & 3250 \\
\hline $\mathrm{pH}$ & 5.6 & $5.3-6.0$ & 5.9 & 7.2 & $6.6-7.6$ & 7.3 \\
\hline Alkalinity (mequiv. $1^{-!}$) & 0.03 & $0.01-0.05$ & 0.03 & 0.28 & $0.19-0.34$ & 0.26 \\
\hline
\end{tabular}




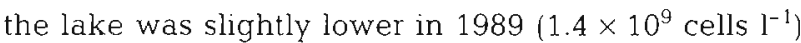
than in $1990\left(1.8 \times 10^{9}\right.$ cells $\left.\mathrm{l}^{-1}\right)$ when the experiments were started. During both years, the phytoplankton biomass in the lake was on the increase when the experiments were started. At that time the phytoplankton composition was Chrysophyceae $(52 \%$ of total phytoplankton biomass), Dinophyceae (23\%), Chlorococcales (18\%), and Cryptophyceae (5\%) in 1989, and Chrysophyceae (29\%), Dinophyceae $(6 \%)$, Chlorococcales (61\%), and Cryptophyceae (4\%) in 1990. Further information about the lake and experiments carried out in it are given in Bell et al. (1993), Bell \& Tranvik (1993), Blomqvist et al. (1993, 1995), Vrede (1996), Blomqvist (1996, 1997), and Stensdotter-Blomberg (1998).

Experimental set-up. Basically identical experiments were carried out in June 1989 (before liming, acidic), and June 1990 (after liming, slightly alkaline). Amounts of inorganic nutrients $\left(\mathrm{PO}_{4}\right.$ and $\left.\mathrm{NO}_{3}\right)$ and metazoan zooplankton were manipulated in transparent plastic bags (300 l vol.). Ten bags, attached to a wooden frame in the lake, were filled with water from $1 \mathrm{~m}$ depth (for a detailed description of the experimental set-up, see Vrede 1996). The water was filtered through $100 \mu \mathrm{m}$ mesh netting to remove large zooplankton. Zooplankton from the lake was then collected in a $300 \mu \mathrm{m}$ mesh net and added to the bags so that there were 5 pairs of bags, each with a different concentration of zooplankton biomass (Fig. 1). The zooplankton additions were kept within the limits of the natural variation in the lake (maximum approx. 4 times the average zooplankton concentration in the lake). In 1989, zooplankton was added to the bags on 2 occasions: on Day 1 (before the first sampling) and on Day 4 (after the second sampling). The second zooplankton addition was carried out because the zooplankton additions on the start day in 1989 resulted in very low zooplankton concentrations. To 1 set of bags representing each of the 5 zooplankton concentrations, $10 \mu \mathrm{g} \mathrm{Pl}^{-1} \mathrm{KH}_{2} \mathrm{PO}_{4}$ and $100 \mu \mathrm{g} \mathrm{N} \mathrm{I}^{-1} \mathrm{KNO}_{3}$ were added (Fig. 1). The experiments lasted for $3 \mathrm{wk}$. Water for analyses of bacterioplankton production and abundance, phytoplankton species composition and biomass (including mixotrophic flagellates), heterotrophic flagellate, ciliate, heliozoan, and metazoan zooplankton species composition and biomass, and water chemistry were taken every third day. Sampling procedures are described in detail in Vrede (1996).

Analyses. Bacterioplankton production was measured as ${ }^{3} \mathrm{H}$-thymidine incorporation into macromolecules (Bell 1993), with modifications described in Vrede (1996). Inmediately after sampling, bacterioplankton was preserved in $4 \%$ (final concentration) formaldehyde for enumeration. Bacterioplankton numbers were determined using epifluorescence micro-

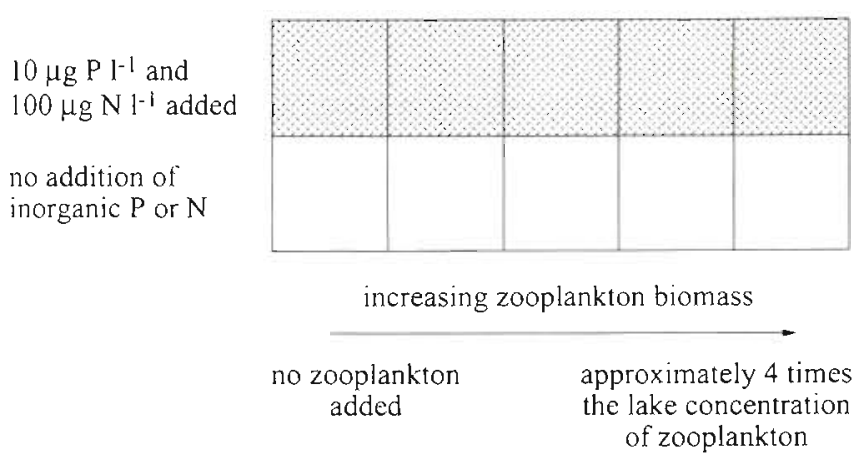

Fig. 1. Design of the experiment in Lake Njupfatet in June 1989 and 1990. Phosphorus (P) was added as $\mathrm{KH}_{2} \mathrm{PO}_{4}$ and nitrogen (N) as $\mathrm{KNO}_{3}$

scopy (1250x magnification) after staining with acridine orange (Hobbie et al. 1977). For each sample, a minimum of 400 cells were counted in at least 20 fields. Cell-specific bacterial production was calculated by dividing bacterioplankton production, measured as ${ }^{3} \mathrm{H}$-thymidine incorporation, by cell numbers. To calculate losses of bacterial biomass, bacterial numbers and the amounts of ${ }^{3} \mathrm{H}$-thymidine incorporated were converted to carbon units. To convert the amounts of incorporated ${ }^{3} \mathrm{H}$-thymidine to cell abundance units, the conversion factor $2 \times 10^{18}$ cells $\mathrm{mol}^{-1}$ was used (Bell 1990). Abundance was converted to cell volume using an average cell volume of $0.06 \mu \mathrm{m}^{3}$, which was determined in another study in the lake (Vrede 1996). Cell volume was then converted to carbon units using a conversion factor of $0.28 \mathrm{pg} \mathrm{C} \mu^{-3}$ (Simon \& Azam 1989). Losses of bacterial biomass were calculated based on bacterial production per day and changes in bacterial biomass per day as described in Vrede (1996).

Samples for enumeration of phytoplankton, potential mixotrophic flagellates, heterotrophic flagellates, ciliates, heliozoan, and metazoan zooplankton were preserved with acidified Lugol's solution immediately after sampling. The organisms were counted in an inverted light microscope after sedimentation. Phytoplankton, heterotrophic flagellates, potential mixotrophic flagellates, ciliates, and heliozoans were counted at 100 and $400 \times$ magnification. Estimates of mixotrophy among flagellates were based on literature data (reviewed by Isaksson 1998). The biomass of potential mixotrophic flagellates was also included in the total phytoplankton biomass. Estimates of bacterivory among ciliates were based on correlations with bacterial biomass and the size of ciliates (StensdotterBlomberg unpubl. data). Heliozoans were assumed not to be bacterivores since no correlation between heliozoan and bacterial biomass was found in a previous study in the lake (Stensdotter-Blomberg 1998). Biovolumes for phytoplankton, heterotrophic flagellates, cili- 
ates, and heliozoans were estimated using geometrical formulas and converted to biomass assuming a density of $1 \mathrm{~g} \mathrm{~cm}^{-3}$. Metazoan zooplankton were counted at 63 and $100 \times$ magnification. Estimates of bacterivory by rotifers and cladocerans were based on literature data (Bern 1987. Arndt 1993). Biomasses of rotifers and crustacean zooplankton were determined using conversion factors for other Swedish lakes (H. Olofsson unpubl. data). Phytoplankton, heterotrophic flagellates, ciliates, heliozoans, and metazoan zooplankton biomasses were converted to carbon units using the following conversion factors: cyanophytes $=22 \%$ of wet weight (Ahlgren 1983); chlorophytes $=16 \%$ of wet weight; other phytoplankton and heterotrophic flagellates $=11 \%$ of wet weight (Lundgren 1978 and references therein); ciliates and heliozoans $=19 \%$ of wet weight (Putt \& Stoecker 1989); crustacean zooplankton $=48 \%$ of dry weight (Andersen \& Hessen 1991); rotifers as for crustacean zooplankton. For more details describing the biological analyses, see Vrede (1996). The water chemistry analyses were done with standard methods as described in Blomqvist et al. (1995). Detailed descriptions of the water chemistry data from the experiments are presented in Blomqvist (1997).

Statistical analyses. Effects of the treatments on bacterioplankton production, bacterioplankton abundance and cell-specific bacterial production were analysed with multiple linear regression at the $5 \%$ significance level. Non-significant variables ( $p>0.05$ ) were excluded from the models. The regressions were carried out on average values for each treatment. All data except the starting values for the response parameters were used in the analyses, since the manipulations were not expected to have effects as early as the first sampling occasion (omitting this sampling point did not affect the results). Total phosphorus (TP) and total nitrogen (TN) were correlated because they were added in the same proportions in the experiments.
Therefore, the regressions were run only on TP. Phosphate was avoided since it was quickly assimilated. Effects on DOC were analysed with linear regression, as described for the bacterial parameters.

\section{RESULTS}

\section{Water chemistry}

In 1989, concentrations of TP increased by $9 \pm 2 \mu \mathrm{g} P$ $1^{-1}$ (average over time \pm standard deviation) and those of $\mathrm{TN}$ by $89 \pm 51 \mu \mathrm{g} \mathrm{N} \mathrm{l^{-1 }}$ in bags that received inorganic nutrients compared with those that did not receive inorganic nutrients. Soluble reactive phosphorus (SRP) was never detectable $\left(<1 \mu \mathrm{g} \mathrm{P}^{-1}\right.$ ) in the bags, owing to its to rapid assimilation. Nitrate concentrations in fertilized bags were approximately $115 \mu \mathrm{g} \mathrm{N}$ $l^{-1}$ on the first day, whereupon they decreased for 7 to

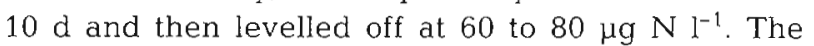
nitrate concentration remained low $\left(<20 \mu \mathrm{g} \mathrm{N} \mathrm{l}^{-1}\right)$ in unfertilized bags.

In 1990, the detectable increase in concentrations of TP and TN in fertilized bags, resulting from additions of inorganic nutrients, was smaller than the corresponding increase in 1989 although there were no differences in nutrient amounts added between years. The concentration of TP increased by $5 \pm 1 \mu \mathrm{g} \mathrm{Pl}^{-1}$, and the concentration of TN by $45 \pm 36 \mu \mathrm{g} \mathrm{N} \mathrm{I}^{-1}$. Only a few of the bags to which phosphorus had been added showed detectable concentrations of SRP on the start day. In bags that had received inorganic nitrogen, nitrate concentrations started at approximately $115 \mu \mathrm{g} \mathrm{N} \mathrm{^{-1 }}$ and decreased steadily for the rest of the experimental period. In unfertilized bags the nitrate concentration remained below the detection limit $\left(<10 \mu \mathrm{g} \mathrm{N} \mathrm{l}^{-1}\right)$.

The concentration of DOC in the bags on the first day was $2.5 \pm 0.4 \mathrm{mg} \mathrm{Cl}^{-1}$ (average \pm standard deviation) in

Table 2. Average metazoan zooplankton and ciliate + heliozoan biomass \pm standard deviation $(n=8)$ during 3 wk in enclosure experiments in June 1989 and 1990 in Lake Njupfatet. +: inorganic phosphorus and nitrogen added $\left(10 \mu g \mathrm{Pl}^{-1}\right.$ as $\mathrm{KH}_{2} \mathrm{PO}_{4}$ and

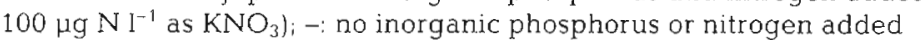

\begin{tabular}{|c|c|c|c|c|c|c|c|c|}
\hline \multirow{3}{*}{$\begin{array}{l}\text { Zooplankton } \\
\text { gradient: }\end{array}$} & \multicolumn{4}{|c|}{ Metazoan zooplankton biomass ( $\left.\mu \mathrm{g} \mathrm{Cl}^{-1}\right)$} & \multicolumn{4}{|c|}{ Ciliate + heliozoan biomass $\left(\mu \mathrm{g} \mathrm{Cl}^{-1}\right)$} \\
\hline & \multicolumn{2}{|c|}{1989} & \multicolumn{2}{|c|}{1990} & \multicolumn{2}{|c|}{1989} & \multicolumn{2}{|c|}{1990} \\
\hline & + & - & + & - & + & - & + & - \\
\hline 1 & $2 \pm 3$ & $2 \pm 2$ & $2 \pm 2$ & $3 \pm 3$ & $48 \pm 56$ & $21 \pm 15$ & $25 \pm 6$ & $13 \pm 7$ \\
\hline 2 & $15 \pm 8$ & $13 \pm 6$ & $71 \pm 18$ & $53 \pm 8$ & $45 \pm 48$ & $11 \pm 7$ & $6 \pm 3$ & $10 \pm 9$ \\
\hline 3 & $50 \pm 26$ & $52 \pm 29$ & $108 \pm 12$ & $86 \pm 22$ & $32 \pm 39$ & $17 \pm 10$ & $8 \pm 8$ & $6 \pm 5$ \\
\hline 4 & $96 \pm 65$ & $98 \pm 57$ & $160 \pm 50$ & $144 \pm 66$ & $17 \pm 9$ & $11 \pm 7$ & $5 \pm 6$ & $4 \pm 6$ \\
\hline 5 & $164 \pm 104$ & $148 \pm 107$ & $250 \pm 134$ & $193 \pm 121$ & 1. $1 \pm 9$ & $6 \pm 6$ & $3 \pm 5$ & $3 \pm 5$ \\
\hline
\end{tabular}

'The lowest number (1) indicates the lowest zooplankton biomass, and the highest number (5) indicates the highest zooplankton biomass 
1989 and $3.1 \pm 0.1 \mathrm{mg} \mathrm{Cl}^{-1}$ in 1990. In both years, average concentrations of DOC during the experiments were negatively correlated with TP (1989: $\mathrm{r}^{2}=0.46, \mathrm{p}=$ $\left.0.03 ; 1990: \mathrm{r}^{2}=0.66, \mathrm{p}=0.004\right)$. The concentration of DOC increased in unfertilized bags during the experiment in 1989 and decreased in fertilized bags in 1990 Average concentrations during the experiment were $3.1 \pm 0.2$ and $3.1 \pm 0.1 \mathrm{mg} \mathrm{Cl}^{-1}$ in unfertilized bags, and $2.8 \pm 0.1$ and $2.9 \pm 0.1 \mathrm{mg} \mathrm{Cl}^{-1}$ in fertilized ones in 1989 and 1990 , respectively. The DOC concentration was negatively correlated with bacterioplankton production in both years $\left(1989: r^{2}=0.43, p=0.04 ; 1990: r^{2}=\right.$ $0.49, p=0.02$ ). The concentration of DOC was never significantly correlated with phytoplankton or metazoan zooplankton biomass ( $p>0.05$ )

\section{Ciliates, heliozoan and metazoan zooplankton}

In 1989, the average metazoan zooplankton biomass ( $\mathrm{n}=8$, all samplings) ranged from 2 to $165 \mu \mathrm{g} \mathrm{C} \mathrm{^{-1 }}$ which corresponds to 0.05 to 4 times the zooplankton concentration in the lake when the experiment started (Table 2). In 1990, metazoan zooplankton was only added on the start day and resulted in a higher zooplankton biomass compared with that in 1989. The average metazoan zooplankton biomass ranged from 2 to $250 \mu \mathrm{g} \mathrm{C} \mathrm{l}^{-1}$, which corresponds 0.05 to 7 times the zooplankton concentrations in the lake when the experiment started (Table 2). The metazoan zooplankton biomass in the lake was 40 and $36 \mu \mathrm{g} \mathrm{C} \mathrm{l}^{-1}$ when the experiments started in 1989 and 1990, respectively.

The added zooplankton community was dominated by the calanoid copepod Eudiaptomus gracilis 186 and $68 \%$ of total metazoan zooplankton biomass in 1989 and 1990, respectively). The cladoceran Diaphanosoma brachyurum made up 5 and $15 \%$ of the total biomass in 1989 and 1990, respectively, and rotifers (mainly Conochilus spp.) accounted for 8 and $13 \%$. The remaining zooplankton biomass consisted of the cladoceran Bosmina in 1989 and cyclopoid copepods in 1990. In bags without zooplankton additions, the community was dominated by rotifers, mainly Kellicottia longispina in 1989 and Conochilus spp. in 1990. In both years, the biomass of metazoan zooplankton in the bags with the 2 highest zooplankton biomasses (both with and without nutrients added) declined. At the end of the experiments, the zooplankton biomasses in these bags were of approximately the same size as those in the bags with the middle concentration of zooplankton.

An addition of zooplankton also implies an addition of nutrients bound in the organisms. There was no significant correlation between TP and zooplankton biomass in 1989. However, in 1990, there was a significant positive correlation between TP and total metazoan zooplankton biomass (linear regression $r^{2}=0.60, p=$ 0.0009 ). The addition of inorganic nutrients resulted in an increased average zooplankton biomass (Table 2), and the addition of zooplankton led to an increase in TP.

The group ciliates + heliozoan was dominated by heliozod, Urotricha sp. $2(\sim 40 \mu \mathrm{m})$ and 2 species of Oligotrichs in 1989, and by Strobilidium sp. and Urotricha sp. $1(\sim 15 \mu \mathrm{m})+$ Balanion sp. (could not be separated) in 1990. The biomass of ciliates + heliozoans was negatively correlated with the metazoan zooplankton biomass both years (Table 2).

\section{Bacterioplankton}

In both years, bacterioplankton production, bacterial abundance and cell-specific bacterial production increased in response to the addition of inorganic nutrients (Fig. 2), and each of these measures were significantly correlated with TP alone (Table 3). In 1989, TP and metazoan zooplankton together explained more of the variation in cell-specific production than TP alone did. Furthermore, in unfertilized bags, both bacterioplankton production and abundance were positively correlated with the biomass of the metazoan zooplankton (linear regression: bacterial production, $\mathrm{r}^{2}$ $=0.92, \mathrm{p}=0.009$; bacterial abundance, $\mathrm{r}^{2}=0.97, \mathrm{p}=$ 0.003 ), but this was not the case in fertilized bags. In 1990, bacterial production, cell-specific production and abundance were positively correlated with metazoan zooplankton alone (all bags: production, $\mathrm{r}^{2}=0.63$, $\mathrm{p}=0.006$; cell-specific production, $\mathrm{r}^{2}=0.56, \mathrm{p}=0.01$ abundance, $\left.r^{2}=0.42, p=0.04\right)$, but metazoan zooplankton explained less of the variance in the bacterial parameters than TP did. The average bacterial abundance in bags to which no inorganic nutrients had been added was similar in 1989 and 1990 (Fig. 2). In contrast, in fertilized bags, bacterial numbers were higher in 1989 than in 1990.

In 1989, bacterial production and abundance were highest towards the end of the experiments (Figs. 3A,B \& 4A,B). The opposite pattern was found in 1990 when bacterial abundance and production in creased more in the beginning of the experiments (Figs. 3C,D \& 4C,D). In 1989, bacterioplankton production in unfertilized bags did not increase until Days 7 to 10. In bags that had received inorganic nutrients, bacterioplankton production started to increase immediately and reached maxima towards the end of the experiment. During the early part of the experiment bacterioplankton numbers decreased or remained stable in all bags. About half-way through the experiment, numbers started to increase, and maxima were reached at the end of the experiment. Cell-specific 
1989
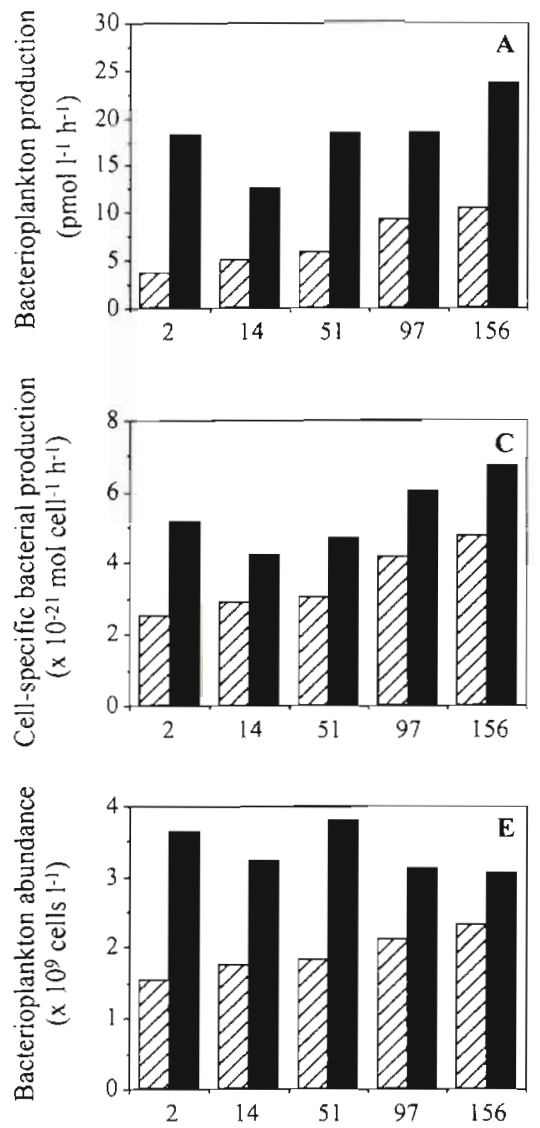

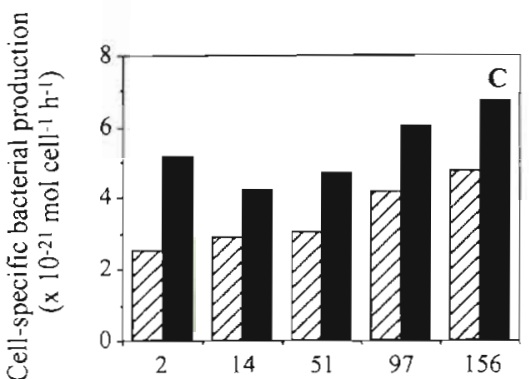

1990
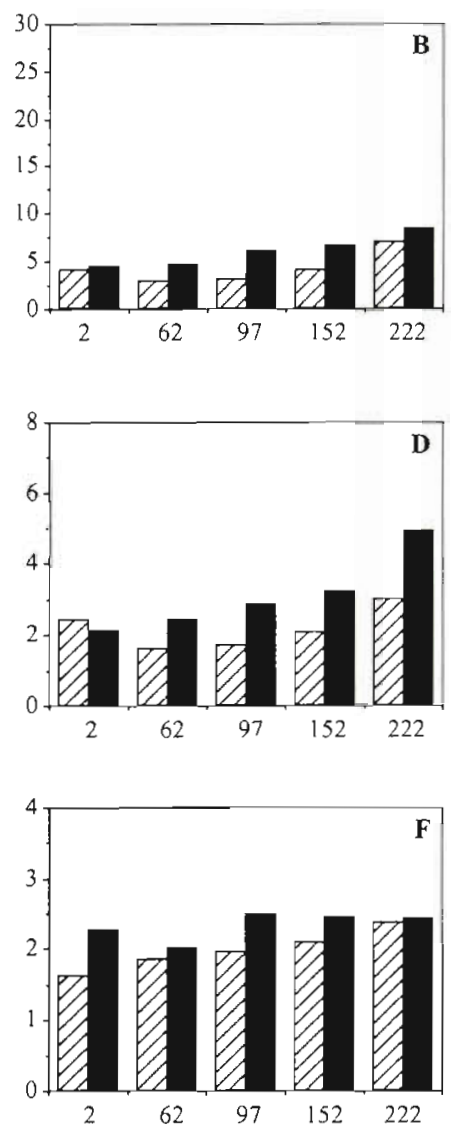

Metazoan zooplankton biomass ( $\left.\mu \mathrm{g} \mathrm{C}^{-1}\right)$

Fig. 2. Average ( $\mathrm{n}=7$, start values excluded) bacterioplankton production (measured as ${ }^{3} \mathrm{H}$-thymidine incorporation rate), cell-specific bacterial production ( ${ }^{3} \mathrm{H}$-thymidine incorporation rate divided by cell numbers) and bacterioplankton abundance versus average metazoan zooplankton biomass in experiments in Lake Njupfatet in June 1989 and 1990. (2) Bags without inorganic nutrients added; ( $\mathbf{C}$ ) Bags to which inorganic phosphorus and nitrogen had been added bacterial production started to increase at the beginning of the experiment and reached maxima around Day 13 in most bags (Fig. 3E,F).

In 1990, bacterioplankton production in unfertilized bags generally reached their maxima on Day 7, whereupon production declined. Bacterial numbers increased during the first half of the experiment and then declined in most bags. In unfertilized bags, cell-specific bacterial production increased slightly in the beginning of the experiment and then decreased (Fig. $3 \mathrm{H}$ ). In bags that had received inorganic nutrients, cell-specific bacterial production was highest at the end of the experiment (Fig. 3G).

\section{Potential bacterial grazers and losses in bacterioplankton biomass}

Potential bacterial grazers in Lake Njupfatet were mixotrophic flagellates, heterotrophic nanoflagellates, ciliates, rotifers and cladocerans. In 1989, on average, $80 \%$ of the bacterial production did not appear as new biomass. In 1990, bacterial production was lower than the calculated losses of bacterial biomass. On average, $135 \%$ of the bacterial production was lost. On a carbon basis, more bacterial biomass was lost in fertilized bags than in unfertilized ones both years (Table 4). Losses of bacterial biomass increased with increasing total metazoan zooplankton biomass in 1990 . but no clear trend of this type was found in 1989.

Table 3. Effects of total phosphorus and metazoan zooplankton biomass on bacterial parameters determined by regression analyses in enclosure experiments in June 1989 and 1990 in Lake Njupfatet. All bags were used in the regressions. BP: bacterioplankton production; BA: bacterioplankton abundance; CBP. cell-specific bacterial production: TP: total phosphorus; ZOO: metazoan zooplankton; ns: not significant $p>0.05$. Only significant regressions are shown.

\begin{tabular}{|c|c|c|c|c|c|c|}
\hline \multirow[t]{2}{*}{ Year } & \multirow[t]{2}{*}{ Model } & \multirow[t]{2}{*}{$r^{2}$} & \multicolumn{4}{|c|}{$p$-values } \\
\hline & & & Regression & Intercept & TP & $\mathrm{ZOO}$ \\
\hline \multirow[t]{4}{*}{1989} & $\mathrm{BP}=1.2 \mathrm{TP}$ & 0.86 & 0.0001 & ns & 0.0001 & - \\
\hline & $\mathrm{BA}=0.15 \mathrm{TP}$ & 0.85 & 0.0002 & ns & 0.0002 & - \\
\hline & $C B P=0.21 \mathrm{TP}$ & 0.66 & 0.004 & ns & 0.004 & - \\
\hline & $\mathrm{CBP}=0.17 \mathrm{TP}+0.01 \mathrm{ZOO}$ & 0.85 & 0.001 & ns & 0.003 & 0.01 \\
\hline \multirow[t]{3}{*}{1990} & $\mathrm{BP}=0.39 \mathrm{TP}$ & 0.90 & $<0.0001$ & ns & $<0.0001$ & - \\
\hline & $\mathrm{BA}=1.3+0.06 \mathrm{TP}$ & 0.74 & 0.001 & 0.0001 & 0.001 & - \\
\hline & $\mathrm{CBP}=0.20 \mathrm{TP}$ & 0.80 & 0.0004 & ns & 0.0004 & - \\
\hline
\end{tabular}


At low metazoan zooplankton concentrations, mixotrophic flagellates dominated on a biomass basis among all potential bacterial grazers both years (Fig. 5). As the total metazoan zooplankton concentrations increased, so did the biomass of potential bacterivores rotifers and cladocerans. In 1989, no phagotrophic nanoflagellates were found. In 1990, Katablepharis ovalis dominated the small biomass of heterotrophic nanoflagellates. The dominant mixotrophic flagellates (on a biomass basis) were Ochromonadaceae spp. ( 5 to $10 \mu \mathrm{m}$ ) and Ochromonadaceae spp. (3 to $4 \mu \mathrm{m}$ ) in 1989, and Ochromonadaceae spp. (5 to $10 \mu \mathrm{m})$, Dinobryon sociale var. americanum, and Dinobryon crenulatum in 1990 . The bacterivores ciliates, rotifers and cladocerans important in 1990 were the same as those that had dominated in 1989. Bacterial grazers were represented by Strobilidium sp. among ciliates, Kellicottia longispina and Conochilus spp. among the rotifers and by Diaphanosoma brachyurum and Bosmina sp. among the cladocerans.

In 1989, the total biomass of potential bacterivores was low on the starting day (Fig. 4E,F). Thereafter the biomass increased and reached a maximum around Day 7 , whereupon it decreased. The increase in bacterial grazers was due both to growth and to the second addition of metazoan zooplankton (after the second sampling). In 1990, the total biomass of bacterivores was high at the beginning of the experiment and decreased thereafter in most cases (Fig. 4G, H). The biomass of rotifers made up almost half of the total biomass of potential bacterial grazers on the first day. However, rotifer biomass decreased rapidly during the experiment. The biomass of cladocerans was also high on the starting day and
Phosphorus and nitrogen added No inorganic nutrients added
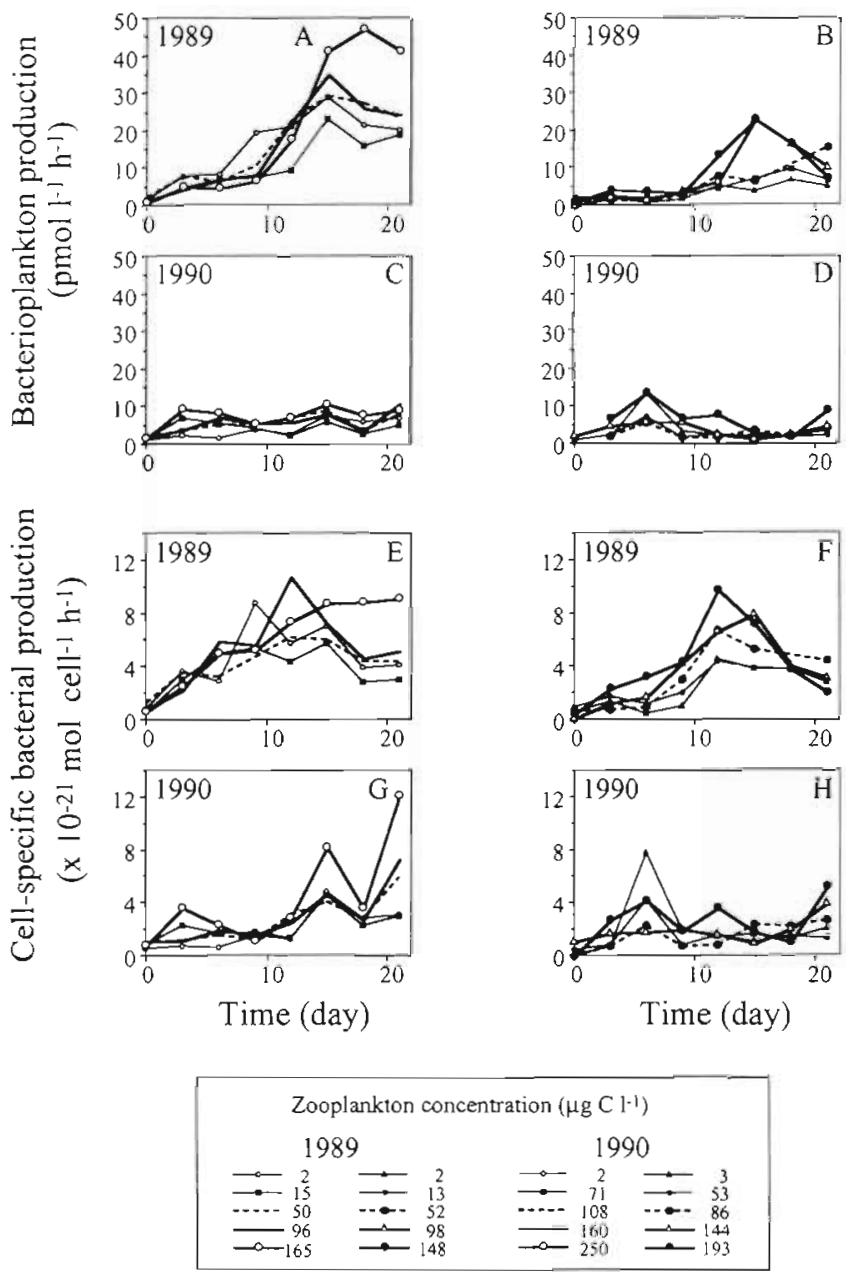

Fig. 3. Bacterioplankton production (measured as ${ }^{3} \mathrm{H}$-thymidine incorporation rate) and cell-specific bacterial production $\left({ }^{3} \mathrm{H}\right.$ thymidine incorporation rate divided by cell numbers) versus time in experiments in Lake Njupfatet in June 1989 and 1990

Table 4. Losses in bacterial biomass and the percentage of bacterial production that did not appear as new biomass in experiments in June 1989 and 1990 in Lake Njupfatet. +: inorganic phosphorus and nitrogen added $\left(10 \mu g \mathrm{Pl}^{-1}\right.$ as $\mathrm{KH}_{2} \mathrm{PO}_{4}$ and $100 \mu \mathrm{g}$ $\mathrm{N} \mathrm{I}^{-1}$ as $\mathrm{KNO}_{3}$ ); -: no inorganic phosphorus or nitrogen added

\begin{tabular}{|c|c|c|c|c|c|c|c|c|}
\hline \multirow{3}{*}{$\begin{array}{l}\text { Zooplankton } \\
\text { gradient }^{\alpha}\end{array}$} & \multicolumn{4}{|c|}{ Bacterioplankton losses $\left(\mu \mathrm{g} \mathrm{C}^{-1} \mathrm{~h}^{-1}\right)$} & \multicolumn{4}{|c|}{ Bacterial lossses/bacterial production $(\%)$} \\
\hline & \multicolumn{2}{|c|}{1989} & \multicolumn{2}{|c|}{1990} & \multicolumn{2}{|c|}{1989} & \multicolumn{2}{|c|}{1990} \\
\hline & + & - & + & - & + & - & + & - \\
\hline 1 & 0.42 & 0.13 & 0.17 & 0.11 & 80 & 114 & 114 & 123 \\
\hline 2 & 0.20 & 0.15 & 0.20 & 0.12 & 35 & 92 & 141 & 168 \\
\hline 3 & 0.37 & 0.17 & 0.27 & 0.15 & 91 & 102 & 144 & 159 \\
\hline 4 & 0.39 & 0.11 & 0.29 & 0.17 & 71 & 69 & 143 & 125 \\
\hline 5 & 0.61 & 0.21 & 0.35 & 0.23 & 75 & 69 & 125 & 111 \\
\hline
\end{tabular}


Phosphorus and nitrogen added
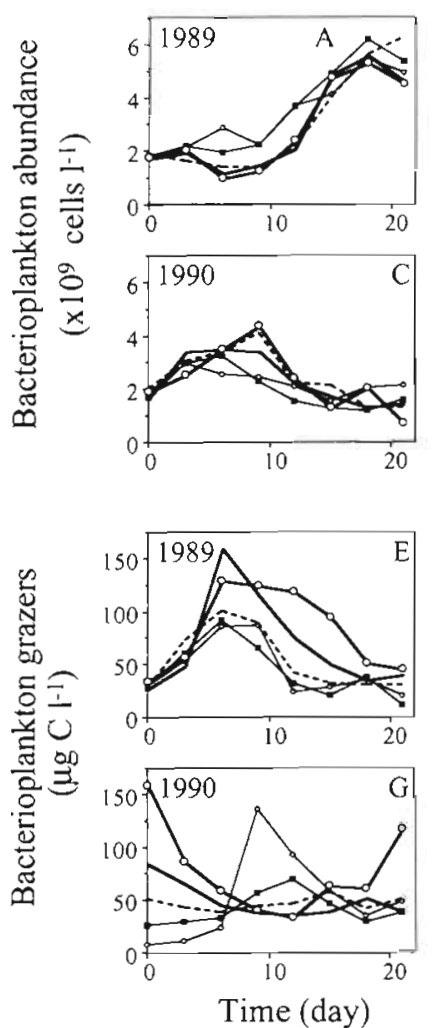

No inorganic nutrients added
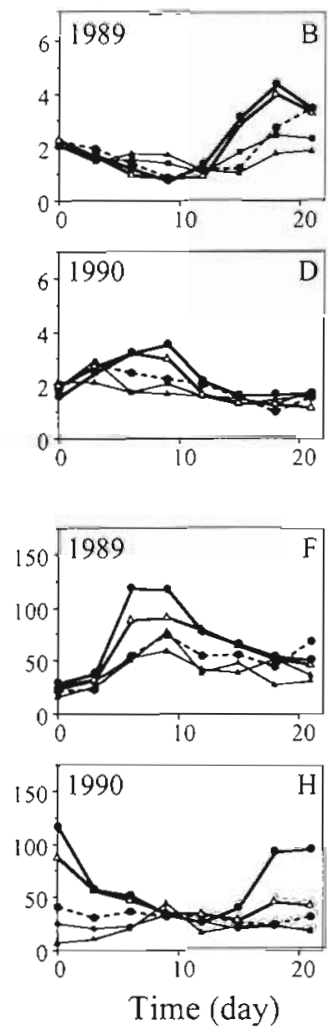

Fig. 4. Bacterioplankton abundance and biomass of bacterial grazers versus time in experiments in Lake Njupfatet in June 1989 and 1990. Symbols as in Fig. 3

Phosphorus and nitrogen added
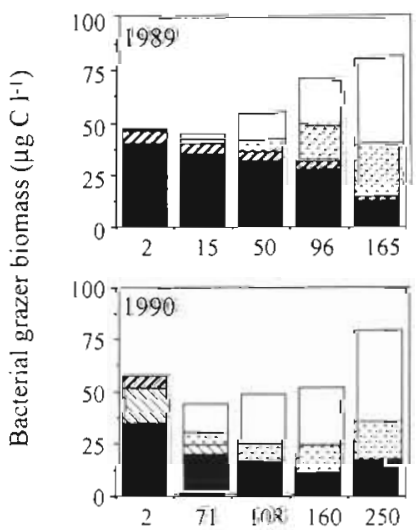

No inorganic nutrients added
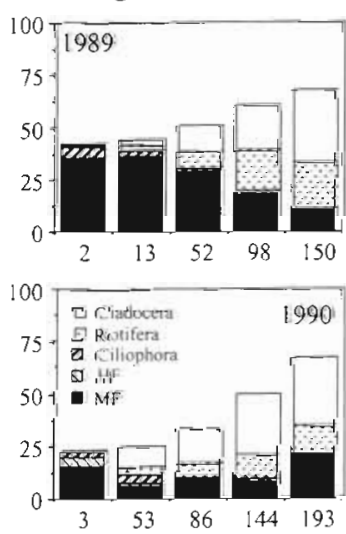

Metazoan zooplankton biomass ( $\mu \mathrm{g} \mathrm{C} \mathrm{l1)}$

Fig. 5. Average biomass of bacterial grazers $(n=8)$ versus average metazoan zooplankton biomass in experiments in Lake Njupfatet in June 1989 and 1990. HF: heterotrophic flagellates; MF: mixotrophic flagellates

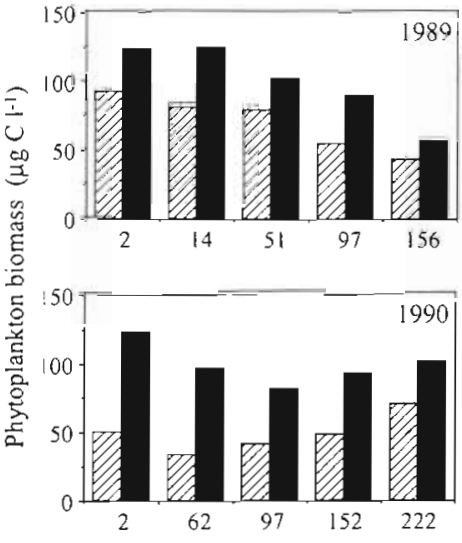

Metazoan zooplankton biomass $\left(\mu \mathrm{g} \mathrm{C}^{-1}\right)$

Fig. 6. Average phytoplankton biomass $(n=7$, start values excluded) versus average metazoan zooplankton biomass in experiments in Lake Njupfatet in June 1989 and 1990. (U) Bags without inorganic nutrients added; (a) bags to which inorganic phosphorus and nitrogen had been added

decreased with time, but to a lesser extent compared with the rotifers. The biomass of bacterivores protozoans (flagellates and ciliates) showed the opposite pattern, with the lowest biomass registered in the beginning of the experiment. Their biomass increased with time and usually peaked in the middle of the experiment (data not shown).

\section{Phytoplankton}

In 1989, phytoplankton biomass increased in response to the input of inorganic nutrients and decreased with increasing zooplankton biomass (Fig. 6). The phytoplankton community was generally dominated (on a biomass basis) by Chrysophyceae and Dinophyceae. In bags with high zooplankton biomass, Chlorococcales also became important. The most important $(>10 \%)$ species on a biomass basis (over all bags and time) were Gymnodinium cf. uberrimum, Ochromonadaceae spp. (5 to $10 \mu \mathrm{m}$ ), Ochromonadaceae spp. ( 3 to $4 \mu \mathrm{m}$ ) and Gymnodinium cf. lacustre. The response of the phytoplankton community is presented in detail elsewhere (Blomqvist 1997). None of the bacterioplankton parameters were significantly correlated to phytoplankton biomass in 1989

In 1990 as well, phytoplankton. biomass increased in response to the input of inorganic nutrients and decreased with increasing zooplankton biomass (Fig. 6). The phytoplankton community was dominated (on a biomass basis) by Chlorococcales except for 1 unfertilized bag without zooplankton, in which Chrysophyceae and Cryptophyceae dominated. The most important (>10\%) species on a biomass basis 
(over all bags and time) were Dictyosphaerium cf. botrytella and Ochromonadaceae spp. (5 to $10 \mu \mathrm{m}$ ). Neither bacterioplankton production nor cell-specific bacterial production were significantly correlated with phytoplankton biomass. Bacterioplankton abundance, on the other hand, was weakly positively correlated with phytoplankton biomass $\left(\mathrm{r}^{2}=0.43, \mathrm{p}=\right.$ $0.04)$.

\section{DISCUSSION}

\section{Effects of nutrients}

In both years, growth of the bacterioplankton community in early summer (June) was stimulated by the addition of inorganic $P$ and $N$, but the magnitudes of the increases differed between years. The stimulation of bacterial growth by inorganic nutrients could have been a direct effect of increased nutrient availability as well as an indirect effect mediated via phytoplankton, since phytoplankton growth was also stimulated. In the latter case the stimulation of phytoplankton growth would have resulted in an increased release of organic compounds that bacteria could utilize. Both direct (Morris \& Lewis 1992, Le et al. 1994, Schweitzer \& Simon 1995) and indirect (Wang et al. 1992) stimulation of bacterioplankton growth by inorganic nutrients have been reported previously from freshwater systems. In the present study, bacterial abundance and production as well as phytoplankton biomass were positively correlated with concentrations of inorganic nutrients. However, the correlation between these 2 planktonic groups was weak. Neither primary production nor the extracellular release of organic compounds were measured in these experiments. In a system with phytoplankton grazers in which only phytoplankton biomass is determined, it is difficult to evaluate the importance of phytoplankton as a carbon source for bacteria and the potential coupling between the planktonic groups. If the stimulation of bacterioplankton growth had been due only to an increased release of organic compounds from phytoplankton, DOC concentrations in fertilized bags should have increased or remained unchanged compared with those in unfertilized bags. However, the fact that DOC concentrations were lower in fertilized enclosures than in unfertilized ones while bacterial production and biomass showed the opposite pattern indicates that bacterioplankton must have been able to use at least a fraction of the DOC pool when they were supplied with inorganic nutrients. It was not possible to determine whether the DOC mainly utilized by the bacteria was newly produced or organic carbon that had been available since the beginning of the experiments. Together, these results indicate that bacterial growth could not have been limited by organic carbon alone. Instead, bacterioplankton production must have been limited by inorganic nutrients alone or in combination with organic carbon.

Phosphate and nitrate were added together, which made it difficult to distinguish between the separate effects of the 2 nutrients. The P:N ratio of added nutrients (molar ratio of 1:22) was based on the P:N ratio of particulate organic matter in the lake. However, this ratio forces the system towards a shortage of $\mathrm{P}$ compared with $N$, since the average $P: N$ ratio is $1: 11$ for bacteria (Fagerbakke et al. 1996) and 1:16 for phytoplankton (Reynolds 1984). That such a shortage of $P$ relative to $N$ did indeed develop is supported by the water chemistry data; i.e. the nitrate added to the bags in 1989 was not consumed, and nitrate was available throughout the experiment in 1990 although it gradually decreased. In addition, since inorganic nitrogen was available in the lake when the experiments started, the effects of the nutrient additions were mainly due to the increase in $\mathrm{P}$.

\section{Effects of zooplankton}

Metazoan zooplankton only contributed significantly to the regressions on the bacterial parameters in 1989. That year, metazoan zooplankton stimulated bacterioplankton cell-specific production, but had no effect on bacterial numbers or production (when the whole data set was used in the analyses). The biomass of potential bacterivores protozoans (ciliates, heterotrophic and mixotrophic flagellates) generally decreased with increasing metazoan zooplankton biomass in the bags. Increasing metazoan zooplankton biomass could thereby result in decreasing grazing pressure by protozoans on bacteria (a trophic cascade). If the metazoan zooplankton effect was due to reduced protozoan grazing, zooplankton should probably have had a positive effect on bacterioplankton abundance. In 1989, zooplankton biomass stimulated bacterial production and led to increased bacterial abundance in treatments where no inorganic nutrients had been added. However, zooplankton did not have these effects in fertilized bags. If this zooplankton-induced increase in bacterial production was an effect of a trophic cascade, one would have expected to see such an increase in the fertilized bags as well. However, no such trend was observed, and in 1990 the bacterial losses even increased with increasing zooplankton biomass.

Another factor that argues against a trophic cascade is that the total biomass of potential bacterial grazers increased with increasing metazoan zooplankton, as metazoan zooplankton includes some rotifers and 
cladocerans that can feed on bacteria. However, since no specific bacterial grazing experiments were conducted, and the group 'potential bacterial grazers' was mainly based on literature data on bacterivory, these data should be interpreted with caution. For example, among the mixotrophic flagellates some certainly photosynthesised, and other bacterivores may have fed on phytoplankton as well. The biomass of bacterial grazers may therefore have been overestimated. The calculated losses of bacterial biomass should also be interpreted with care since they are based on literature conversion factors that can vary. However, assuming that the conversion factors are the same between the bags it can be concluded that bacterial losses on a carbon basis were higher in fertilized bags than in unfertilized ones.

An alternative explanation of the positive correlation between cell-specific bacterial production and metazoan zooplankton is that zooplankton regenerated nutrients that bacteria could utilize. Zooplankton activity has been shown to be important in providing organic substrates for bacterial growth in both oligotrophic and eutrophic waters (Vadstein et al. 1989, Peduzzi \& Herndl 1992). In addition, zooplankton can be important in regenerating phosphorus and nitrogen (Sterner et al. 1995). Laboratory experiments have shown that Eudiaptomus gracilis (which was the dominating zooplankton species in Lake Njupfatet) can directly stimulate bacterioplankton growth (Vrede 1998). Since a positive effect of zooplankton on both bacterioplankton production and biomass was only found in unfertilized bags in 1989, in the present study, I suggest that the effect of metazoan zooplankton on bacteria was due mainly to nutrient regeneration by metazoan zooplankton rather than to a trophic cascade. The results indicate that inorganic nutrients released by zooplankton were only important at low nutrient concentrations since there were no measurable effects on bacterial number or production in fertilized bags. However, the possibility cannot be excluded that zooplankton was also a source of organic substrates in view of the fact that cell-specific bacterial production increased regardless of whether or not inorganic nutrients were added. This implies that phytoplankton carbon indirectly released through zooplankton activity might have been utilized by bacteria.

In 1989, there was low grazing pressure on many bacterial grazers owing to the low biomass of metazoan zooplankton (before the second zooplankton addition); thus, protozoans were the dominant bacterivores during the first days. This, in turn, probably led to high grazing pressure on bacteria and explains why bacterial abundance did not increase even though the cell-specific bacterial production was high (especially in fertilized bags).

\section{Comparison between the years}

Low $\mathrm{pH}$ has been reported to have a neutral or negative effect on microbial activity (Kollig \& Hall 1982, McKinley \& Vestal 1982, Rao \& Dutka 1983). Tranvik et al. (1994) did not find any differences in bacterial activity between acid and limed humic lakes in southern Sweden. My findings are in accordance with the results of Tranvik et al. (1994) since the lower $\mathrm{pH}$ (5.6 in 1989 vs 7.2 in 1990) did not have a negative impact on bacterioplankton activity. Since liming (in November 1989) resulted in an increase in the concentration of DOC and a decrease in that of TP, one would expect the response of bacterial production to an input of inorganic nutrients to have been stronger after liming. To the contrary, bacterial responses to nutrients were smaller in 1990 than in 1989.

During the experiments in 1989 the phytoplankton community was dominated $(70 \%$ of total phytoplankton biomass) by phytoplankton suitable as food for herbivorous zooplankton (based on size and digestibility), whereas in 1990 this group of phytoplankton only constituted $40 \%$ of the phytoplankton biomass (Blomqvist 1997). The response of the phytoplankton community to nutrient additions, on a biomass basis, was stronger in 1990, when inedible phytoplankton dominated, than in 1989. If more phytoplankton were grazed in 1989 , this could have led to a higher release of dissolved compounds (both inorganic and organic). This, in turn, could explain the higher growth rate of bacterioplankton that year. The same trend was found in experiments carried out in the lake in August 1989 and 1990 (the results are presented in detail in Vrede 1996). In August 1989, the phytoplankton community was dominated ( $72 \%$ of total phytoplankton biomass) by the inedible cyanophyte Merismopedia tenuissima, and the bacterioplankton community responded weakly to additions of nutrients. In August the following year, $76 \%$ of the phytoplankton community consisted of zooplankton-edible phytoplankton, and the bacterioplankton community responded more strongly to the nutrient additions. This implies that the species composition of phytoplankton may affect the transfer of bacterial substrates, and thereby have a strong impact on bacterioplankton growth. Arguing against this hypothesis is the fact that zooplankton did not have any significant negative effect on the group 'edible phytoplankton' in August 1990 (Blomqvist 1996). However, since primary production was not measured, it is difficult to estimate the actual growth rate of phytoplankton.

To summarize, this study shows that inorganic nutrients can limit bacterioplankton growth (alone or in combination with organic carbon supplied from phytoplankton) in an oligotrophic clearwater lake. The in- 
crease in bacterial biomass was smaller than expected based on the production measurements, especially in fertilized bags, indicating that there was strong grazing pressure on bacteria. Additions of metazoan zooplankton resulted in increased cell-specific bacterial production one year. Although this increase may have been due to a reduction in bacterivore biomass, some of the increased growth was probably due to nutrient regeneration by zooplankton. Furthermore, the results suggest that the species composition of phytoplankton can affect the growth of bacterioplankton.

Acknowledgements. I am indebted to the late Russell $T$ Bell for supervision and ideas. Peter Blomqvist, Hans Olofsson and Ulrika Stensdotter-Blomberg kindly allowed me to use their data on phytoplankton, metazoan zooplankton and protozoan zooplankton, respectively. Raul Figueroa provided field assistance and conducted the chemical analyses. Peter Blomqvist. Ingvar Sundh, Tobias Vrede, and 3 anonymous referees offered constructive criticism on earlier drafts of the manuscript, and David Tilles corrected the English. This work was supported by a grant from the Swedish Environmental Protection Board (SNV) to Peter Blomqvist and grants from the Swedish Natural Science Research Council (NFR) and SNV to R. T. Bell.

\section{LITERATURE CITED}

Ahlgren G (1983) Comparison of methods for estimation of phytoplankton carbon. Arch Hydrobiol 98:489-508

Andersen T, Hessen DO (1991) Carbon, nitrogen, and phosphorus content of freshwater zooplankton. Limnol Oceanogr 36:807-814

Andersson NJ, Blomqvist P, Renberg I (1997) An experimental and palaeoecological study of algal responses to lake acidification and liming in three central Swedish lakes. Eur J Phycol 32:35-48

Arndt $H$ (1993) Rotifers as predators on components of the microbial web (bacteria, heterotrophic flagellates, ciliates)-a review. Hydrobiologia 225/226:231-246

Baines SB, Pace ML (1991) The production of dissolved organic matter by phytoplankton and its importance to bacteria: patterns across marine and treshwater systems. Limnol Oceanogr 36:1078-1090

Bell RT (1990) An explanation for the variability in the conversion factor deriving bacterial cell production from incorporation of $\left[{ }^{3} \mathrm{H}\right]$ thymidine. Limnol Oceanogr 35: 910-915

Bell RT (1993) Estimating production of heterotrophic bacterioplankton via incorporation of tritiated thymidine. In: Kemp PF, Sherr BF, Sherr EB, Cole JJ (eds) Handbook in methods in aquatic microbial ecology. Lewis Publisher, Boca Raton, p 495-503

Bell RT, Tranvik L (1993) Impact of acidification and liming on the microbial ecology of lakes. Ambio 22:325-330

Bell RT, Vrede K, Stensdotter U, Blomqvist P (1993) Stimulation of the microbial food web in an oligotrophic, slightly acidified lake. Limnol Oceanogr 38:1532-1538

Bern L (1987) Zooplankton grazing on [methyl $-{ }^{3} \mathrm{H}$ ] thymidinelabelled natural particle assemblages: determination of filtering rates and food selectivity. Freshwat Biol 17:151-159

Berninger UG, Findlay BJ, Kuuppo-Leinokki P (1991) Proto- zoan control of bacterial abundances in freshwater. Limnol Oceanogr 36:139-147

Blomqvist P (1996) Late summer phytoplankton responses to experimental manipulations of nutrients and grazing in unlimed and limed Lake Njupfatet, central Sweden. Arch Hydrobiol 137:425-255

Blomqvist P (1997) Early summer phytoplankton responses to experimental manipulations of grazing and nutrients in unlimed and limed Lake Njupfatet, central Sweden. Arch Hydrobiol 140:321-346

Blomqvist P, Bell RT, Olofsson $H$, Stensdotter U, Vrede K (1993) Pelagic ecosystem responses to nutrient additions in acidified and limed lakes in Sweden. Ambio 22:283-289

Blomqvist P, Bell RT, Olofsson H, Stensdotter U, Vrede K (1995) Plankton and water chemistry in Lake Njupfatet before and after liming. Can J Fish Aquat Sci 52:551-565

Brett $M$, Wichowski $K$, Lubnow $F$, Muellersolger A, Elser J, Goldman C (1994) Species-dependent effects of zooplankton on planktonic ecosystem processes in Castle Lake, California. Ecology 75:2243-2254

Burns CW, Schallenberg M (1996) Relative importance of copepods, cladocerans and nutrients on the microbial food web of a mesotrophic lake. J Plankton Res 18:683-714

Fagerbakke KM, Heldal M, Norland S (1996) Content of carbon, nitrogen, oxygen, sulfur and phosphorus in native aquatic and cultured bacteria. Aquat Microb Ecol 10 $15-27$

Hessen D (1985) The relation between bacterial carbon and dissolved humic compounds in oligotrophic lakes. FEMS Microbiol Ecol 31:215-223

Hessen DO, Nygaard K, Salonen K, Vähätalo A (1994) The effect of substrate stoichiometry on microbial activity and carbon degradation in humic lakes. Environ Int 20:67-76

Hobbie JE, Daley RJ, Jasper S (1977) Use of nucleopore filters for counting bacteria by epifluorescence microscopy. Appl Environ Microbiol 33:1225-1228

Isaksson A (1998) Phagotrophic phytoflagellates in lakes-a literature review. Arch Hydrobiol Spec Iss Adv Limnol 51: $63-90$

Jumars PA, Penry DL, Baross JA, Perry MJ, Frost B (1989) Closing the microbial loop: dissolved carbon pathway to heterotrophic bacteria from incomplete ingestion, digestion and absorption in animals. Deep-Sea Res 36:483-495

Kollig HP, Hall TL (1982) The effect of acid perturbation on a controlled ecosystem. Water Air Soil Pollut 17:225-233

Le J, Wehr JD, Campbell L (1994) Uncoupling of bacterioplankton and phytoplankton production in freshwater is affected by inorganic nutrient limitation. Appl Environ Microbiol 60:2086-2093

Lundgren A (1978) Experimental lake fertilization in the Kuokkel area, northern Sweden: changes in sestonic carbon and the role of phytoplankton. Verh Int Verein Limnol 20:863-868

McKinley VL, Vestal JR (1982) Effects of acid on plant litter decomposition in an arctic lake. Appl Environ Microbiol 43:1188-1195

Morris DP, Lewis WM Jr (1992) Nutrient limitation of bacterioplankton growth in Lake Dillon, Colorado. Limnol Oceanogr 37:1179-1192

Münster U, Chróst RJ (1990) Origin, composition and microbial utilization of dissolved organic matter. In Overbeck J, Chróst RJ (eds) Aquatic microbial ecology: biochemical and molecular approaches. Springer, New York, p 8-46

Peduzzi P, Herndl GJ (1992) Zooplankton activity fueling the microbial loop: different growth response of bacteria from oligotrophic and eutrophic waters. Limnol Oceanogr 37 : $1087-1092$ 
Putt M, Stoecker DK (1989) An experimentally determined carbon:volume ratio for marine 'oligotrichous' ciliates from estuarine and coastal waters. Limnol Oceanogr 34:1097-1103

Rao SS, Dutka BJ (1983) Influence of acid precipitation on bacterial populations in lakes. Hydrobiologia 98:153-157

Reynolds CS (1984) The ecology of freshwater phytoplankton. Cambridge University Press, Cambridge

Rheinheimer G (1992) Aquatic microbiology, 4th edn. John Wiley \& Sons Ltd, Chichester

Sanders RW, Porter KG, Bennett SJ, DeBiase AE (1989) Seasonal patterns of bacterivory by flagellates, ciliates, rotifers, and cladocerans in a freshwater planktonic community. Limnol Oceanogr 34:673-687

Sanders RW, Caron DA, Berninger UG (1992) Relationship between bacteria and heterotrophic nanoplankton in marine and freshwaters: an inter-ecosystem comparison. Mar Ecol Prog Ser 86:1-14

Schweitzer B, Simon M (1995) Growth limitation of planktonic bacteria in a large mesotrophic lake. Microb Ecol 30:89-104

Àimek K, Straskrabova V (1992) Bacterioplankton production and protozoan bacterivory in a mesotrophic reservoir. J Plankton Res 14:773-787

Simon M, Azam F (1989) Protein content and protein synthesis rates of planktonic marine bacteria. Mar Ecol Prog Ser 51:201-213

Stensdotter-Blomberg U (1998) Factors controlling pelagic populations of ciliates and heliozoans. Late summer investigations in an acidic lake, before and after liming. J Plankton Res 20:423-442

Sterner RW, Chrzanowski TH, Elser JJ, George NB (1995) Sources of nitrogen and phosphorus supporting the growth of bacterio- and phytoplankton in an oligotrophic Canadian shield lake. Limnol Oceanogr 40:242-249

Sundh I, Bell RT (1992) Extracellular dissolved organic carbon released from phytoplankton as a source for heterotrophic

Editorial responsibility: Karel Simek

Ceské Budèjovice, Czech Republic bacteria in lakes of different humic content. Hydrobiologia 229:93-106

Toolan T, Wehr JD, Findlay S (1991) Inorganic phosphorus stimulation of bacterioplankton production in a mesoeutrophic lake. Appl Environ Microbiol 57:2074-2078

Tranvik LJ (1988) Availability of dissolved organic carbon for planktonic bacteria in oligotrophic lakes of differing humic content. Microb Ecol 16:311-322

Tranvik LJ, Hansson LA (1997) Predator regulation of aquatic microbial abundance in simple foodwebs of sub-Antarctic lakes. Oikos 79:347-356

Tranvik LJ, Höfle MG (1987) Bacterial growth in mixed cultures on dissolved organic carbon from humic and clear waters. Appl Environ Microbiol 53:482-488

Tranvik LJ, Granéli W. Gahnström G (1994) Microbial activity in acidified and limed humic lakes. Can J Fish Aquat Sci $51: 2529-2536$

Vadstein $O$, Harkjerr BO, Jensen A, Olsen $Y$, Reinertsen $\mathrm{H}$ (1989) Cycling of organic carbon in the photic zone of a eutrophic lake with special reference to the heterotrophic bacteria. Limnol Oceanogr 34:840-855

Vareschi $E$ (1994) In-situ experiments on the influence of zooplankton on the phosphate status of bacterio- and phytoplankton. Limnologica 24:1-11

Vrede K (1996) Regulation of bacterioplankton production and biomass in an oligotrophic clearwater lake - the importance of the phytoplankton community. J Plankton Res 18:1009-1032

Vrede $T$ (1998) The role of crustacean zooplankton in pelagic nutrient cycling. Comprehensive summaries of Uppsala dissertations from the Faculty of Science and Technology 365. PhD thesis, Uppsala University

Wang L, Miller TD, Priscu JC (1992) Bacterioplankton nutrient deficiency in a eutrophic lake. Arch Hydrobiol 125: $423-439$

Submitted: July 15, 1997; Accepted: November 24, 1998 Proofs received from author(s): July 14, 1999 